\title{
Original Paper \\ Redescription and extended geographical distribution of Peltaea chiquitana (Malvaceae, Malvoideae)
}

\author{
Aluisio José Fernandes-Júnior ${ }^{1,2,4,5}$, Marco Octávio de Oliveira Pellegrini ${ }^{3}$, Gerleni Lopes Esteves ${ }^{2}$ \\ \& Fábio de Barros ${ }^{2}$
}

\begin{abstract}
Peltaea chiquitana has been a name of dubious identity due to the incomplete original description and original materials lacking fruits. Recent herbaria and field work studies have uncovered new data for this species. Thus, we present a redescription of $P$. chiquitana, including, for the first time, details of column, fruit, and seed morphology. An extended geographical distribution of $P$. chiquitana is presented, based on the first records of the species to Brazil. Furthermore, line drawings, scanning electronic microscope photographs, a distribution map, and a conservation assessment are presented here.
\end{abstract}

Key words: Cerrado, fruit, new record, redescription, taxonomy.

\begin{abstract}
Resumo
Peltaea chiquitana tem sido um nome de identidade duvidosa devido à descrição original incompleta e aos materiais originais não possuírem frutos. Estudos recentes de herbários e trabalhos de campo realizados trouxeram novos dados sobre essa espécie. Assim, apresentamos uma redescrição de $P$. chiquitana, incluindo a coluna, fruto e semente pela primeira vez. A extensão da distribuição geográfica de $P$. chiquitana é apresentada com base nos primeiros registros para o Brasil. Além disso, são apresentadas ilustrações, microscopia eletrônica de varredura, mapa de distribuição e estado de conservação.
\end{abstract}

Palavras-chave: Cerrado, fruto, novo registro, redescrição, taxonomia.

\section{Introduction}

Peltaea is a Neotropical genus of Malvaceae comprising 19 species (Fernandes-Júnior \& Esteves 2016). The genus is represented by 13 species in Brazil, out of which eight are endemic, occurring especially in the Cerrado domain, the genus' center of diversity (Krapovickas \& Cristóbal 1965; Fernandes-Júnior \& Esteves 2016). The genus can be characterized by the epicalyx bracteoles, morphologically and anatomically, differentiated in pedicel and blade, and by the chromosome numbers $2 \mathrm{n}=50$ or $2 \mathrm{n}=100$ (Krapovickas \& Cristóbal 1965; Fernandes-Júnior \& Esteves 2016). Despite having already been taxonomically revised by
Krapovickas \& Cristóbal (1965), many taxonomic problems persist to this day, especially regarding the distribution and delimitation of many taxa, due to the limited number of herbarium specimens analyzed by these authors.

Peltaea chiquitana was described by Krapovickas \& Cristóbal (1965) based on a single collection, "Krapovickas 9293" (CTES, LIL). The species was characterized by its red corolla, and was said to be native to the Province of Chiquitos, Bolivia. After its description, little attention was given to this species. The name remained obscure and its application doubtful in the absence of any further herbarium collection.

\footnotetext{
${ }^{1}$ Universidade Federal do Maranhão, Centro de Ciências Naturais, Av. Aurila Maria dos Santos Barros Sousa 2010, Lot. Frei Alberto Beretta, 65940-000, Grajaú, MA, Brazil.

${ }^{2}$ Secretaria de Meio Ambiente, Instituto de Botânica, Av. Miguel Estefano 3687, Água Funda, 04301-902, São Paulo, SP, Brazil.

${ }^{3}$ Universidade de São Paulo, Depto. Botânica, R. do Matão 277, Cidade Universitária, 05508-090, São Paulo, SP, Brazil.

${ }^{4}$ ORCID: <https://orcid.org/0000-0003-3443-9364>

${ }^{5}$ Author for correspondence: ajfernandesjunior@gmail.com
} 
The present work aims to report the recent rediscovery of $P$. chiquitana, its first record for Brazil, extending the geographical distribution, and also provide a complete taxonomic analysis based on newly identified specimens, in order to clarify the identity and application of this name. An amendment of the original description is provided, including the first description of column, fruit, and seed characters.

\section{Material and Methods}

The morphological descriptions and phenology of $P$. chiquitana were based on specimens of relevant herbaria. The indumentum description follows Payne (1978) and Harris \& Harris (2001); shapes terminology follows Radford et al. (1974) and Harris \& Harris (2001); inflorescence terminology and morphology follow Radford (1974) and Krapovickas \& Cristóbal (1965), with some modifications; fruit and seed terminology follow Krapovickas \& Cristóbal (1965) and Fryxell (1985, 1988). The conservation assessment is proposed following the recommendations of IUCN Red List Categories and Criteria (IUCN 2017). GeoCAT (Bachman et al. 2011) was used for estimating the Extent of Occurrence (EOO) and the Area of Occurrence (AOO). Species distribution was based on herbaria specimens. The map of the geographical distribution was made using the QGIS program with the geographic coordinates obtained from the SpeciesLink database (SpeciesLink 2015) or data contained on the labels of exsiccates. The classification of the vegetation patterns follows Veloso et al. (1991).

The scanning electron microscopy of trichomes followed Fernandes-Junior et al. (2018), in which the botanical materials were prepared with fragments of dried herbarium specimens and fixed directly on stubs using double-sided tape. Posteriorly, the stubs were coated with gold for three minutes in an SCD 050 ion sputtering device. The eléctron micrographs of trichomes were made on a Philips XL20 scanning eléctron microscope in the Laboratory of Electron Microscopy of the Instituto de Botânica of São Paulo.

\section{Results and Discussion}

Peltaea chiquitana Krapov. \& Cristóbal, Kurtziana 2: 183. 1965. Type: BOLIVIA. SANTA CRUZ: Prov. Chiquitos, Santiago de Chiquitos, 9.II.1958, fl., A. Krapovickas 9293 (Holotype: LIL!; Isotype: CTES!).

Figs. 1;2

Shrubs $0.7-2 \mathrm{~m}$ tall; branches cylindrical, indumentum tomentose, rusty-yellow composed of stellate antrorse trichomes associated with a longitudinal line of stellate trichomes. Leaves with stipules 2-4 mm long, subulate; petioles 3-11 mm long; blades 2-6.9 × 0.8-3.4 cm, ovate-elliptic to ovate, discolor, chartaceous, entire, 5-veined at base, apex acute, margin serrate, ciliolate, base rounded to subcordate, both sides with stellate antrorse trichomes. Flowers chasmogamous, solitary in the axils of leaves or foliaceous bracts or arranged in terminal reduced racemes (capituliform), subtended by foliaceous bracts; pedicels $1-4 \mathrm{~mm}$ long; bracts $1.7-3 \times 0.9-1.5 \mathrm{~cm}$, ovate-elliptic to ovate, both sides with stellate trichomes, adaxial side with a yellowish spot at the base and glabrous at the basal portion, apex acute, margin ciliolate, base rounded, yellow; bracteoles of the epicalyx 11-13, spathulate, both sides with simple and stellate trichomes, margins ciliate, pedicel 3-5 mm long, blade 2-4 $\times$ 1-1.5 mm, elliptic; calyx 5-8 mm long, 25-veined, externally with simple and stellate trichomes; petals $1.5-2.6 \times 1.9-2.2 \mathrm{~cm}$, red with a dark red spot at base, obovate, with simple and stellate trichomes, except the imbricated portions, which are glabrous; staminal tube $1-1.2 \mathrm{~cm}$ long, red, free portions of the stamens arranged in two groups along the tube, yellow; styles 2-3.5 mm, red, erect, exceeding the staminal tube. Mericarps 4-5 mm long, apiculate, dorsal side slightly winged with rounded wings, indehiscent, dorsal side slightly nervate-reticulate, with simple retrorsed and glandular trichomes; column 1-1.2 mm long, cylindrical, slightly enlarged at base; seeds 3-3.4 mm long, trigonous, glabrous. Specimens examined: BOLIVIA. SANTA CRUZ: Prov. Chiquitos, Santiago de Chiquitos, 8.IV.2008, fl., J.R.I. Wood et al. 24311 (CTES); 29.IV.1980, fr., A. Krapovickas \& A. Schinini 36646 (CTES, LPB); $18^{\circ} 20^{\prime} 22^{\prime}$ 'S, 5940'51'W, 7.II.2005, fl., S. Neffa et al. 1911 (CTES, LPB). BRAZIL. MATO GROSSO: Jaciara, Rio Amaral, 21.VIII.1997, fr., G. Hatschbach et al. 67061 (CTES, LIL, MBM). MATO GROSSO DO SUL: Rio Verde, Serra da Pimenteira, 9.II.1974, fl. and fr., G. Hatschbach 33977 (CTES).

Peltaea chiquitana is restricted to the Cerrado and Chaco domains of Bolivia and Brazil (states of Mato Grosso and Mato Grosso do Sul), at altitudes between 330 and $570 \mathrm{~m}$, growing in damp and sandy soils (Fig. 3). This is the first record of this species to the Brazilian territory. Peltaea chiquitana was found in bloom between February and April, and fruiting in February, April and August.

Peltaea chiquitana is known from only seven collections from three localities, all of them outside any conservation unit and in highly deforested areas. Besides that, the species has 


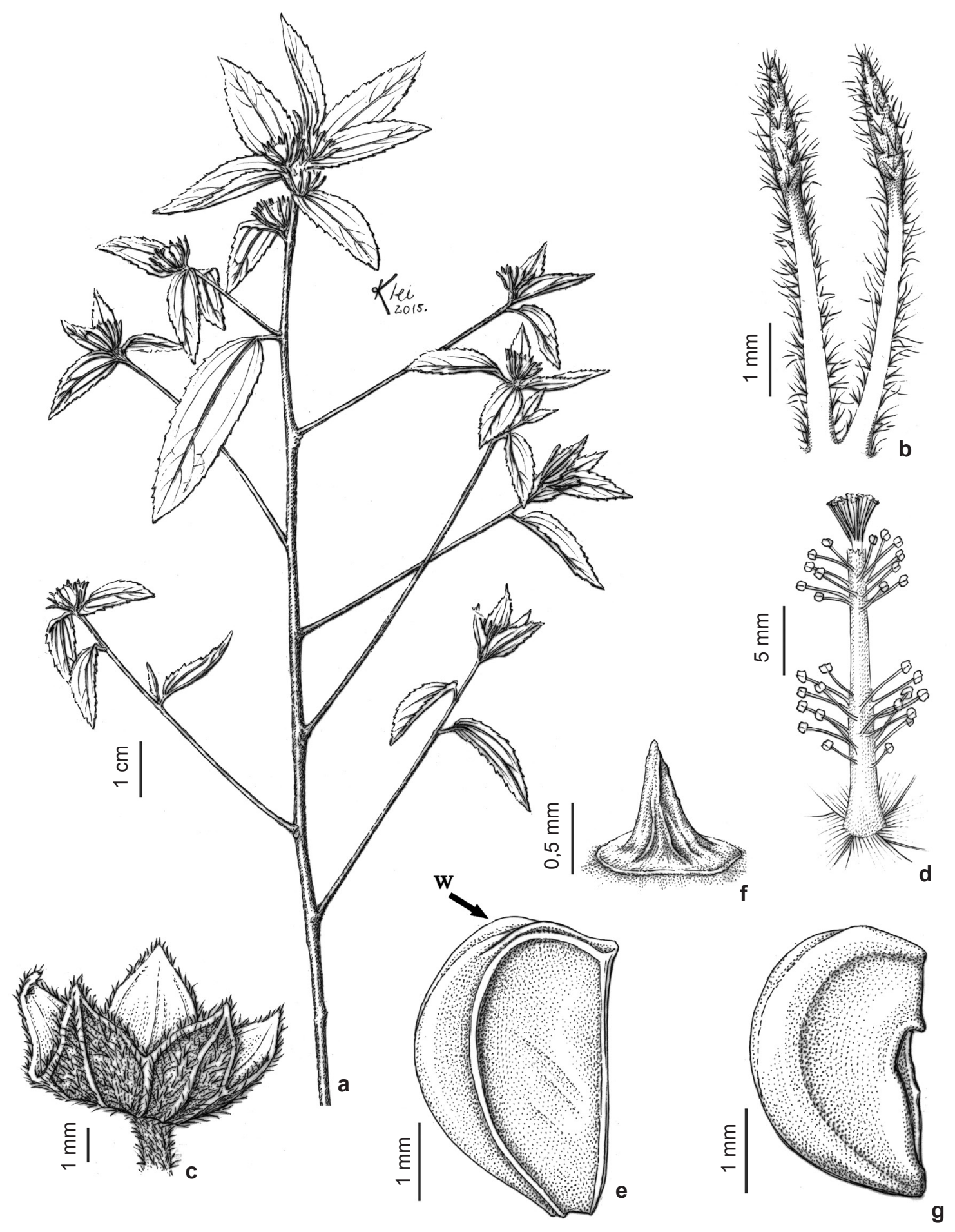

Figure 1 - a-g. Peltaea chiquitana - a. flowering branch; b. bracteoles of the epicalyx; c. calyx (without bracteoles of the epicalyx) showing veins outside (marked) and inside (impressed); d. staminal tube; e. mericarp slightly rounded and winged (w); f. column; g. seed. (a-g. G. Hatschbach et al. 67061). Illustration: Klei Sousa. 

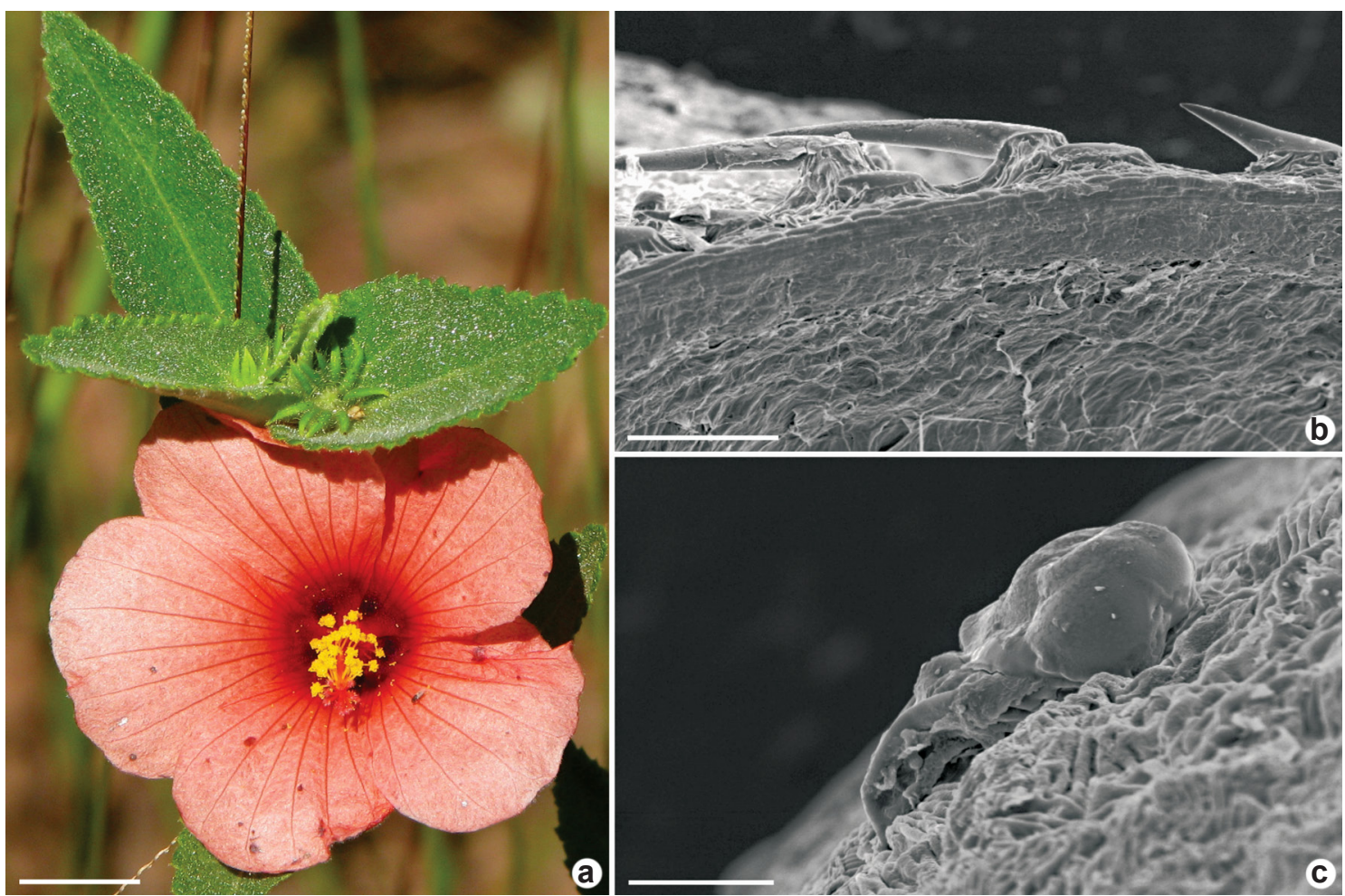

Figure 2 - a-c. Habit and scanning electron micrographs of Peltaea chiquitana - a. flowering branch showing the red flower and foliaceus bracts; $b$. detail of simple retrorse trichomes of the mericarp indumenta; c. detail of a glandular trichome of the mericarp indumentum. Scale bar: $a=1 \mathrm{~cm} ; \mathrm{b}=100 \mu \mathrm{m} ; \mathrm{c}=20 \mu \mathrm{m}$. Field photo by H. Hayala. Microphotographs from Hatschbach et al. 67061.

considerably small EOO $\left(83,670 \mathrm{~km}^{2}\right)$ and AOO $\left(16 \mathrm{~km}^{2}\right)$, severely fragmented population, few mature individuals per subpopulation and is directly threatened by deforestation. Thus, following the IUCN recommendations (IUCN 2017), $P$. chiquitana should be considered Endangered [EN, B2ab (ii, iii, iv)] in its overall distribution.

Peltaea chiquitana is characterized by the rusty-yellow indumentum on the branches with stellate trichomes, red corolla, cylindrical column, slightly enlarged at the base, and by its slightly rounded and winged mericarps. The remaining species of the genus have corolla entirely yellow, or with an orange darker spot at base or ranging from pink to white with a darker spot yellow, reddish or vinaceous at base (Krapovickas \& Cristóbal 1965; Fryxell 1985; Fernandes-Júnior \& Esteves 2016). This species can be readily assigned to the morphologically similar group composed of $P$. riedelii (Gürke) Standl. and P. rupestris A.J. Fernandes-Jr. \& G.L. Esteves mainly due its lanceolate to elliptical leaf blades, foliaceous bracts, and solitary flowers and/or in arranged terminal reduced (capituliform) racemes, always subtended by foliaceous bracts ( $P$. chiquitana, rarely presents solitary flowers in the leaf axils), and glabrous seeds (Krapovickas \& Cristóbal 1965; Fernandes-Júnior \& Esteves 2016). Diagnostic characters differentiating $P$. chiquitana and morphologically similar species are presented in the Table 1.

As aforementioned, P. chiquitana was described based on a single collection. Both the holotype and the isotype possess only flowers, and data regarding fruit, column and seed morphology was unknown, prior to our present contribution. Based on the original materials and description, it is possible to relate $P$. chiquitana with $P$. riedelli and $P$. rupestris, species of the genus with pink flowers. Nevertheless, a proper differentiation of those three morphologically related species was possible only by the examination of fruiting specimens that were discovered on the course of a series of systematic studies of Peltaea 


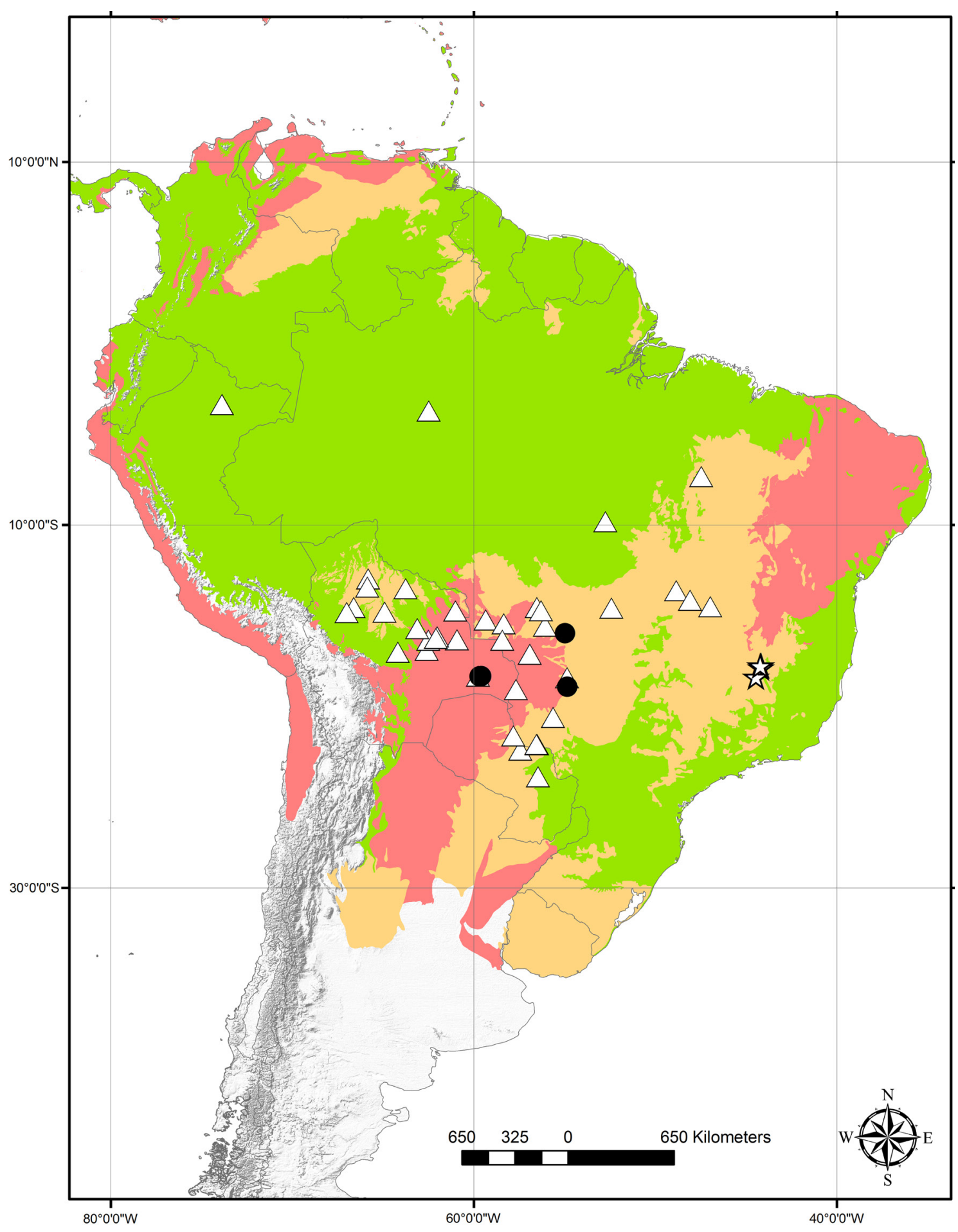

Figure 3 - Geographical distribution of Peltaea chiquitana and closely related species. $\downarrow=P$. rupestris; $\Delta=P$. riedelli; - $P$. chiquitana Green = rainforest; Red = dry forest; Orange = savanna. 
Table 1 - Diagnostic comparison between Peltaea chiquitana and morphologically similar species.

\begin{tabular}{|c|c|c|c|}
\hline Character & Peltaea chiquitana & Peltaea riedeli & Peltaea rupestris \\
\hline Leaf blades veins & 5-7 veined & 3 veined & 5-7 veined \\
\hline Leaf blades consistency & chartaceous & chartaceous & coriaceous \\
\hline Leaf blades indument & $\begin{array}{l}\text { both sides with stellate } \\
\text { antrorsed trichomes }\end{array}$ & $\begin{array}{l}\text { both sides with stellate antrorsed } \\
\text { trichomes, rarely with simple } \\
\text { trichomes on the abaxial side }\end{array}$ & $\begin{array}{l}\text { both sides with stellate } \\
\text { adpressed trichomes }\end{array}$ \\
\hline Bracteoles of epicalyx & spathulate & peltate & spathulate \\
\hline Corolla colour & $\begin{array}{l}\text { red with a dark red spot } \\
\text { at base }\end{array}$ & $\begin{array}{l}\text { entirely yellowish or pinkish with } \\
\text { a vinaceous spot at base or yellow } \\
\text { with a reddish spot at base }\end{array}$ & $\begin{array}{l}\text { pinkish with a red } \\
\text { spot at base }\end{array}$ \\
\hline Mericarps indument & $\begin{array}{l}\text { simple retrorsed and } \\
\text { glandular trichomes }\end{array}$ & simple antrorsed trichomes & $\begin{array}{l}\text { simple retrorsed and } \\
\text { glandular trichomes }\end{array}$ \\
\hline Mericarps dorsal side & $\begin{array}{l}\text { slightly nervate-reticulate; } \\
\text { winged }\end{array}$ & $\begin{array}{l}\text { slightly nervate-reticulate; } \\
\text { not winged }\end{array}$ & smooth; not winged \\
\hline Mericarps appendix & apiculate & apiculate & muticous \\
\hline Mericarps dehiscence & indehiscent & dehiscent & dehiscent \\
\hline Column & $\begin{array}{l}\text { cylindrical, slightly } \\
\text { enlarged at base }\end{array}$ & $\begin{array}{l}\text { cylindrical, slightly enlarged } \\
\text { at base }\end{array}$ & conic \\
\hline Seeds & trigonous & reniform & trigonous \\
\hline Habitat & $\begin{array}{l}\text { Cerrado and Chaco domains, } \\
\text { growing in damp and sandy } \\
\text { soils at elevations between } \\
330 \text { and } 570 \mathrm{~m}\end{array}$ & $\begin{array}{l}\text { Cerrado domain, growing in clay } \\
\text { or rocky soils in damp or flooded } \\
\text { environments at elevations } \\
\text { between } 40 \text { and } 570 \mathrm{~m}\end{array}$ & $\begin{array}{l}\text { Cerrado domain, } \\
\text { growing in rocky } \\
\text { outcrops at elevations } \\
\text { between } 950 \text { and } 1210 \mathrm{~m}\end{array}$ \\
\hline Distribution & $\begin{array}{l}\text { Bolivia and Brazil } \\
\text { (MS, MT) }\end{array}$ & $\begin{array}{l}\text { Bolivia, Brazil (GO, MA, MS, MT), } \\
\text { Colombia, Paraguay and Peru }\end{array}$ & Brazil (MG) \\
\hline
\end{tabular}

(Krapovickas \& Cristóbal 1965; Fryxell 1985; Fernandes-Júnior \& Esteves 2016).

The taxonomy and species delimitation in Peltaea greatly rely on indumentum, inflorescence architecture, bracteoles of the epicalyx, and fruit morphology (Krapovickas \& Cristóbal 1965; Fernandes-Júnior \& Esteves 2016). The examination of the herborized specimens of Peltaea is difficult when characters such as corolla coloration are not described on the exsiccate labels. Aside from the aforementioned diagnostic characters, column, fruit and seed represent key characters for the correct application of names in Peltaea.

\section{Acknowledgments}

AJFJ and MOOP are grateful to Coordenação de Aperfeiçoamento de Pessoal de Nível Superior (CAPES) for their Doctoral scholarships. FB acknowledges the productivity grant from $\mathrm{CNPq}$ (Process 304506/2013-3). We also thank Klei R. Sousa for the line drawings, Rafael Felipe de Almeida for the confection of the map, the curators and staff of the all visited herbaria for their kindness and for sending loans to the SP herbarium. Furthermore, the first author is grateful to the great botanist and mentor, Dr. Antonio Krapovickas (in memoriam), for his teachings in Botany and Malvaceae.

\section{References}

Bachman S, Moat J, Hill AW, Torre J \& Scott B (2011) Supporting Red List threat assessments with GeoCAT: geospatial conservation assessment tool. In: Smith V \& Penev L (eds.) e-Infrastructures for data publishing in biodiversity science. ZooKeys 150: 117-126. Available at <http://geocat.kew.org>. Access on February 2017. 
Fernandes-Júnior AJ \& Esteves GL (2016) Three new species of Peltaea (Malvaceae, Malvoideae) from the Cerrado of Brazil. Phytotaxa 275: 75-82.

Fernandes-Júnior AJ, Ferrucci MS \& Gil ASB (2018) Triumfetta multiglandulosa (Malvaceae, Grewioideae): a new species from the remnants of the Brazilian Atlantic Forest in the state of Goiás, Brazil. Systematic Botany 43: 1005-1010.

Fryxell PA (1985) Four new species of Malvaceae from Venezuela. Systematic Botany 10: 273-281.

Fryxell PA (1988) Malvaceae of Mexico. Systematic Botany Monographs. The American Society of Plants Taxonomist, Michigan. 522p.

Harris JG \& Harris MW (2001) Plant identification terminology, $2^{\text {nd }}$ ed. Spring Lake, Utah. $216 \mathrm{p}$.

IUCN (2017) Guidelines for using the IUCN red list categories and criteria. Version 12. Prepared by the standards and petitions subcommittee. IUCN,
Gland, Cambridge. Available at $<$ https://portals. iucn.org/library/sites/library/files/documents/RL2001-001-2nd.pdf $>$. Access in February 2017.

Krapovickas A \& Cristóbal CL (1965) Revisión del género Peltaea (Malvaceae). Kurtziana 2: 135-216.

Payne WW (1978) A glossary of plant hair terminology. Brittonia 30: 239-255.

Radford AE, Dickison WC, Massey JR \& Bell CR (1974) Vascular Plants Systematics. Harper \& Row Publisher, New York. 891p.

SpeciesLink (2015) Ferramenta geoLoc da rede SpeciesLink. Available at $<$ http://splink.cria.org. br/geoloc $>$. Access in January 2017.

Veloso HP, Rangel-Filho AL \& Lima JCA (1991) Classificação da vegetação brasileira, adaptada a um sistema universal. Departamento de Recursos Naturais e Estudos Ambientais. IBGE, Rio de Janeiro. 124p. 